\title{
Comparing the molecular graph degeneracy of Wiener, Harary, Balaban, Randić and ZEP topological indices
}

\section{ZOIŢA-MĂRIOARA BERINDE}

\section{ABSTRACT.}

The aim of this paper is to show that the ZEP topological index has better discrimination power than four well known topological indices in molecular chemistry: Balaban index, Harary index, Randić index, and Wiener index.

\section{REFERENCES}

[1] Balaban, A. T., Applications of graph theory in chemistry, J. Chem. Inf. Comput. Sci., 25 (1985), 334-343

[2] Balaban, A. T., Can topological indices transmit information on properties but not on structure?, J. Comput. Aided Design, 19 (2005), 651-660

[3] Barysz, M., Jashari, G., Lall, R. S., Srivastaya, V. K. and Trinajstić, N., On the Distance Matrix of Molecules Containing Heteroatoms, in Chemical Applications of Graph Theory and Topology, King, R. B. (Ed), Elsevier, Amsterdam, 1983, 222-230

[4] Berinde, Z., Applications of Molecular Topology in the Study of Physico-chemical Properties of Organic Compounds (in Romanian), Cub Press 22, Baia Mare, 2001

[5] Berinde, Z., Consideraţii privind modelarea matricială a compuşilor halogenaţi, Rev. Chim. (Bucureşti), 52 (2001), No. 12, 788-792

[6] Berinde, Z., Un nou indice topologic de tip Randić, Rev. Chim. (Bucureşti), 53 (2002), No. 1, 812-816

[7] Berinde, Z. and Drinkal, C., On a local invariant for modeling molecular double bonds graphs, Chem. Bull. "Politehnica" Univ. (Timişoara), 49 (63) (2004), No. 1-2, 8-10

[8] Berinde Z. and Drinkal, C., Molecular modelling of molar refraction for alkanes, Chem. Bull. "Politehnica" Univ. (Timişoara), 49 (63) (2004), No. $1-2,4-7$

[9] Berinde, Z., Vertex- and edge-weighted molecular graphs for amines, Rev. Roum. Chim., 51 (2006), No. 11, 1131-1135

[10] Berinde, Z., QSPR modelling of molar volume of alkanes using the ZEP topological index, Creat. Math. Inform. 17 (2008), No. 3, $308-312$

[11] Berinde, Z., Matrix mathematical models used in the representation of molecular structures, Sc. Stud. Res. Ser. Math. Inf., 19 (2009), No. 2, 59-70

[12] Berinde, Z., A QSPR study of hydrophobicity of phenols and 2-(aryloxy- $\alpha$-acetyl)-phenoxathiin derivatives using the topological index ZEP, Creat. Math. Inform., 22 (2013), No. 1, 33-40

[13] Diudea M. and Ivanciuc, O., Molecular Topology (in Romanian), Comprex, Cluj-Napoca, 1995

[14] Estrada, E., Edge adjacency relationships in molecular graphs containing heteroatoms: A novel topological index related to molar volume, J. Chem. Inf. Comput. Sci., 35 (1995), 701-707

[15] Faulon, J.-L., Brown, W. M., and Martin, S., Reverse engineering chemical structures from molecular descriptors: how many solutions?, J. Comput. Aided Design, 19 (2005), 637-650

[16] Ivanciuc, O., Balaban, T.-S., and Balaban, A., Chemical graphs with degenerate topological indices based on information on distances, J. Math. Chem., 14 (1993), 21-33

[17] Nikolić, S., Plavšić, D. and Trinastić, N., On the Balaban-like topological indices, MATHCH, 44 (2001), 361-386

[18] Plavšić, D., Nikolić, S. and Trinastić, N., On the Harary index for the characterisation of chemical graphs, J. Math. Chem., 12 (1993), 235-250

[19] Randić, M., On characterization of molecular branching, J. Amer. Chem. Soc., 97 (1975), 6609-6615

[20] Randić, M., Novel Graph Theoretical Approach to Heteroatoms in Quantitative Structure-Activity Relationships, Chemometrics Intel. Lab. Syst., 10 (1991), 213-227

[21] N. Trinajstić, Chemical Graph Theory , 2nd revised edition, vol. II, CRC Press, Boca Raton, Florida, 1992

[22] Wiener, H., Structural determination of paraffins boiling points, J. Amer. Chem. Soc., 69 (1947), 17-20

[23] Dragon Evaluation for Windows (Software for Molecular Descriptors calculations), Version 5.4, 2006, Talete srl, http://www.talete.mi.it/

[24] Molecular Modeling Pro, Version 6.10 trial, www.norgwyn.com/

DePartMENT OF CHEMistry AND Biology

North University CENTER at Baia Mare

TECHNICAL UNIVERSITY OF CLUJ-NAPOCA

Victoriei 76, 430122 BAia MARE, ROMANIA

E-mail address: zoitaberinde@ubm.ro

E-mail address: zoita_berinde@yahoo.com

Received: 23.02.2014; In revised form: 19.08.2014; Accepted: 22.09.2014

2010 Mathematics Subject Classification. 92E10.

Key words and phrases. ZEP topological index, Balaban index, Wiener idex, Randić index, degeneracy. 